of stress management (W D Johnson, personal communication)..$^{12}$

The costs of starting counselling schemes have been addressed elsewhere, ${ }^{3}$ but a final constituent is evaluating how they work and their impact. If the general outcome is as good as the reaction reported here by the few doctors who already have such experience, or from industry," that will be an important change in postgraduate medical training.

1 Department of Health and Social Security. Hospital medical staffing: achiezing a balance. London: DHSS, 1986

2 Department of Health and Social Security. Hospital medical staffing: achiering a balance-plan for action. London: DHSS, 1987.

3 Hunter S. Careers counselling for hospital doctors in the training grades. London: British Medical Association - Hospital Junior Staff Committee, 1989.
+ Firth-Cozens J. Emotional distress in junior house officers. Br Med $f$ 1987:295:533-6

Firth-Cozens J. Stress in medical undergraduates and house officers. Brf Hosp Med 1989;41:161-4.

6 Allen I. Doctors and their careers. London: Policy Studies Institute, 1988

7 McInnes D. Medical and dental staffing prospects in the NHS in England and Wales in 1987. Health Trends 1988;20:101-9.

8 Women in Medicine. Careers for women in medicine: planning and putfalls. Lom in Medicine. Careers for women

9 Altmaier EM, Johnson SR, Tarico VS, Laube D. An empirical specification of residency performance dimensions. Obstet Gynecol 1988;72:126-30.

10 Quattlebaum TG. Sperry JB. A computerized system for evaluation of residents and residency experiences. Am $\mathcal{F}$ Dis Child 1988;142:758-62.

11 Allinson T, Cooper CL, Reynolds P. Stress counselling in the workplace. The Psychologist 1989;2:384-8.

12 Gangster DC, Maves BT. Managing organizational stress: a field experiment. f Appl Psychol 1982;67:533-42

Accepted 15 December 1989,

\title{
HIV testing in patients with end stage renal disease
}

\author{
Andrew Stevens, Janet Little, Susan Kerr, Paula Kilbane, Ciaran Doherty
}

Department of Public

, Mint Wing, Centre Authority, London

W2 1NY

Andrew Stevens, MFCM, senior registrar

Eastern Health and Socia Services Board, Belfast

Janet Little, MFCM, consultant in public health medicine

Susan Kerr, BSC, statistician Paula Kilbane, FFCM, consultant in public health medicine

\section{Regional Department of} Nephrology, Belfast City

Ciaran Doherty, MRCP, consultant nephrologist Dr Stevens.

Br Med f 1990;300:447-9 Hospital, Belfast BT9 7AB

Correspondence to:

\begin{abstract}
One hundred and twenty eight British and Irish nephrologists were questioned about their policy for HIV testing of patients with end stage renal failure being considered for renal replacement therapy. A total of $101(79 \%)$ replied. In the case of candidates for dialysis roughly one third of respondents tested only people they considered at risk of infection with HIV and nearly one fifth considered testing unnecessary. In the case of candidates for transplantation routine HIV testing was carried out by 68 of 100 nephrologists; 22 tested only patients "at risk" and 10 did not test. A positive HIV test result was considered by most but not all respondents $(63 / 86)$ to exclude patients from transplantation. Twenty four of 88 nephrologists considered that HIV positivity should exclude patients from haemodialysis, but only seven of 87 would exclude such patients from peritoneal dialysis. Similar attitudes pertained for patients with end stage renal failure who refused HIV testing. Testing with the patient's knowledge and consent was the policy of two thirds of nephrologists, but a patient's signature was obtained by only 24 of 88.
\end{abstract}

There should be a consensus on practice for HIV testing of patients with end stage renal failure.

\section{Introduction}

Neither the clinical usefulness nor the ethics of HIV antibody testing in hospital practice when it is not part of the admitting clinical question have been fully resolved.' Furthermore, consent for testing has become a major ethical and legal issue concerning both the BMA and the General Medical Council..-5 The principle of testing only with the patient's consent has been well established, based on the potentially grave

TABLE I-Response rates among units (at least one respondent) and nephrologists according to numbers of cases of AIDS reported in their districts ${ }^{\star}$

\begin{tabular}{|c|c|c|c|c|}
\hline & \multicolumn{2}{|c|}{ Units } & \multicolumn{2}{|c|}{ Nephrologists } \\
\hline & Total & Response & Total & Response \\
\hline \multicolumn{5}{|l|}{ Districts with: } \\
\hline High reported incidence of AIDS $\geqslant 50$ cases $)$ & 10 & 9 & 24 & 16 \\
\hline Medium reported incidence of AIDS $10-49$ cases & 22 & 21 & 43 & 37 \\
\hline Low reported incidence of AIDS $<10$ cases $)$ & 34 & 30 & 61 & 46 \\
\hline Unknown† & & & - & 2 \\
\hline Total & 66 & 60 & 128 & 101 \\
\hline
\end{tabular}

"Cumulative reports to PHLS Communicable Disease Surveillance Centre by February 1989

tRespondents not identifiable. consequences of a positive result and the equivocal benefits of available treatment. ${ }^{6}$ Even offering the test with consent requires careful counselling and always requires justification.

A setting in which conventional strategies for testing have been questioned is that of patients with end stage renal failure. ${ }^{8-11}$ In haemodialysis units treatment of HIV positive patients may require precautions similar to those evolved for hepatitis B carriers. After renal transplantation in an HIV positive patient the immunosuppressive treatment needed to prevent rejection would be likely to worsen the immunodeficiency state and accelerate the disease process. ${ }^{12}$ And in all forms of renal replacement therapy demand exceeds supply, so that a degree of rationing has been the rule. ${ }^{1314}$

We report a survey carried out to determine the attitudes of British and Irish nephrologists to HIV testing of patients with end stage renal failure and to see how these attitudes influenced the strategy for treatment.

\section{Subjects and methods}

A closed, self administered questionnaire was sent to all consultant nephrologists in the United Kingdom and Republic of Ireland identified from the European dialysis and transplantation lists and the United Kingdom Transplantation Society annual report. The questionnaire asked which patients are offered or given the HIV test, whether this is with the patient's knowledge and consent, and what effect a positive test result or refusing the test would have on the selection of the patient for renal replacement. Patients were subdivided into candidates for peritoneal dialysis, haemodialysis, and renal transplantation. Nephrologists were classified according to whether the district they worked in had a high, medium, or low reported incidence of AIDS, defined as more than 50 cases, 10-49 cases, or fewer than 10 cases of AIDS reported to the Public Health Laboratory Service Communicable Disease Surveillance Centre by February 1989.

\section{Results}

One hundred and twenty eight nephrologists in 66 units were contacted, of whom $101(79 \%)$ in 60 units replied (table I). The response rate among nephrologists was higher in districts beginning to encounter AIDS than in districts with a high reported incidence of AIDS and districts in which reported cases were still 
rare. In terms of units, however, only one district with a high reported incidence of AIDS was unrepresented.

\section{RATES OF TESTING}

The HIV test was routinely offered to candidates for peritoneal dialysis by 48 of 99 respondents, to candidates for haemodialysis by 51 of 99 , and to candidates for transplantation by 68 of 100 (table II). Whatever the treatment strategy the proportion of nephrologists routinely offering the test to patients increased with the reported incidence of AIDS in their area.

The proportions of respondents whose policy was to offer the HIV test only to people they considered at risk were 33 out of 99 in the case of candidates for peritoneal dialysis, 30 out of 99 in the case of candidates for haemodialysis, and 22 out of 100 in the case of candidates for transplantation (in whom the test was more frequently routine). The proportions did not vary substantially between areas with high and low reported incidences of AIDS

Not offering the test at all as a routine was more common in areas with a low or medium reported incidence of AIDS and more frequent in the case of candidates for haemodialysis and peritoneal dialysis than in the case of candidates for transplantation. Respondents in areas with a high reported incidence of AIDS all tested candidates for transplantation.

\section{EXCLUSIONS FROM TREATMENT}

A positive HIV test result was considered by seven of 87 respondents to exclude a patient from peritoneal dialysis by 24 of 88 respondents to exclude a patient

TABLE II - Rates of routinely offering HIV testing to candidates for peritoneal dialysis, haemodialysis, and transplantation. Figures are numbers of nephrologists who answered question $\star$

\begin{tabular}{|c|c|c|c|c|}
\hline & $\begin{array}{c}\text { Districts with } \\
\text { high } \\
\text { incidence } \\
\text { of AIDS }\end{array}$ & $\begin{array}{l}\text { Districts with } \\
\text { medium } \\
\text { incidence } \\
\text { of AIDS }\end{array}$ & $\begin{array}{c}\text { Districts with } \\
\text { low } \\
\text { incidence } \\
\text { of AIDS }\end{array}$ & Total ${ }^{\star}$ \\
\hline \multicolumn{5}{|l|}{ Peritoneal dialysis: } \\
\hline Yes & 9 & 19 & 18 & 48 \\
\hline Only patients considered at risk & 6 & 12 & 15 & 33 \\
\hline No & 1 & 4 & 13 & 18 \\
\hline Total respondents & 16 & 35 & 46 & 99 \\
\hline \multicolumn{5}{|l|}{ Haemodialysis: } \\
\hline Yes & 11 & 20 & 18 & 51 \\
\hline Only patient's considered at risk & 4 & 11 & 15 & 30 \\
\hline No & 1 & 4 & 13 & 18 \\
\hline Total respondents & 16 & 35 & 46 & 99 \\
\hline \multicolumn{5}{|l|}{ Transplantations: } \\
\hline Yes & 12 & 26 & 28 & 68 \\
\hline Only patients considered at risk & 4 & 7 & 11 & 22 \\
\hline No & 0 & 3 & 7 & 10 \\
\hline Total respondents & 16 & 36 & 45 & 100 \\
\hline
\end{tabular}

*Question asked: "Do you routinely offer the following categories of patients the HIV test?"

tTotal includes two "unknowns."

TABLE III - Proportions of nephrologists who would exclude patients from peritoneal dialysis, haemodialysis, or transplantation if they had a positive HIV test result or refused the test

\begin{tabular}{|c|c|c|c|c|c|}
\hline & & $\begin{array}{c}\text { Districts with } \\
\text { high } \\
\text { incidence } \\
\text { of AIDS }\end{array}$ & $\begin{array}{l}\text { Districts with } \\
\text { medium } \\
\text { incidence } \\
\text { of AIDS }\end{array}$ & $\begin{array}{c}\text { Districts with } \\
\text { low } \\
\text { incidence } \\
\text { of AIDS }\end{array}$ & Total ${ }^{\star}$ \\
\hline \multicolumn{6}{|l|}{ Test positives: } \\
\hline Peritoneal dialysis & $\begin{array}{l}\text { Would exclude } \\
\text { Total }\end{array}$ & $\begin{array}{r}0 \\
14\end{array}$ & $\begin{array}{r}4 \\
34\end{array}$ & $\begin{array}{r}2 \\
37\end{array}$ & $\begin{array}{r}7 \\
87\end{array}$ \\
\hline Haemodialysis & $\begin{array}{l}\text { Would exclude } \\
\text { Total }\end{array}$ & $\begin{array}{r}3 \\
14\end{array}$ & $\begin{array}{l}10 \\
34\end{array}$ & $\begin{array}{l}10 \\
38\end{array}$ & $\begin{array}{l}24 \\
88\end{array}$ \\
\hline Transplantation & $\begin{array}{l}\text { Would exclude } \\
\text { Total }\end{array}$ & $\begin{array}{l}10 \\
13\end{array}$ & $\begin{array}{l}22 \\
32\end{array}$ & $\begin{array}{l}29 \\
39\end{array}$ & $\begin{array}{l}63 \\
86\end{array}$ \\
\hline $\begin{array}{l}\text { Test refusals: } \\
\text { Peritoneal dialysis }\end{array}$ & $\begin{array}{l}\text { Would exclude } \\
\text { Total }\end{array}$ & $\begin{array}{r}4 \\
14\end{array}$ & $\begin{array}{l}10 \\
34\end{array}$ & 2 & $\begin{array}{l}17 \\
83\end{array}$ \\
\hline Haemodialysis & $\begin{array}{l}\text { Would exclude } \\
\text { Total }\end{array}$ & $\begin{array}{r}6 \\
14\end{array}$ & $\begin{array}{l}14 \\
34\end{array}$ & $\begin{array}{r}8 \\
33\end{array}$ & $\begin{array}{l}29 \\
83\end{array}$ \\
\hline Transplantation & $\begin{array}{l}\text { Would exclude } \\
\text { Total }\end{array}$ & $\begin{array}{l}10 \\
14\end{array}$ & $\begin{array}{l}22 \\
33\end{array}$ & $\begin{array}{l}18 \\
32\end{array}$ & $\begin{array}{l}52 \\
81\end{array}$ \\
\hline
\end{tabular}

«Total includes two "unknowns." from haemodialysis, and by 63 of 86 respondents to exclude a patient from transplantation (table III). The pattern was fairly consistent among the three types of district (that is, as classified by the reported incidence of AIDS), with the exception that districts with a high reported incidence of AIDS were more likely to offer peritoneal dialysis and haemodialysis and less likely to offer transplantation to patients positive for HIV.

Similar but on the whole higher rates of exclusion from dialysis were reported for patients who refused the test than for those who were HIV positive. In areas with a low reported incidence of AIDS, however, patients who refused the test had a higher rate of acceptance for transplantation than patients who tested HIV positive.

\section{KNOWLEDGE AND CONSENT}

Testing without the patient's knowledge ("not usually" or "never" with the patient's knowledge) was reported by four of 92 respondents, and testing without seeking the patient's consent was reported by five of 88 respondents (table IV). Two thirds of respondents reported always seeking the patient's consent.

The way in which consent was recorded was very variable. Twenty four of 88 respondents sought the patient's written consent, 18 recorded consent in the notes, 27 accepted verbal consent, and 19 relied on implied consent. Implied and verbal consent were used by only six of 15 respondents in areas with a high reported incidence of AIDS whereas in areas with medium and low reported incidences they sufficed for 19 of 34 and 20 of 37 respondents respectively.

\section{Discussion}

This survey of British and Irish nephrologists shows a continued upward trend in the number of nephrologists carrying out HIV testing of candidates for renal replacement therapy. The European Dialysis and Transplant Association found that the proportion of centres testing at least some patients had increased from $28 \%$ to $70 \%$ (not distinguishing types of treatment) from 1985 to $1987 . .^{15}$ Our study, completed early in 1989 , indicates that $90 \%$ of nephrologists in centres offering dialysis and transplantation now carry out testing of at least some patients.

There is also a considerable variation in HIV testing practice of candidates for renal replacement therapy. Testing is commoner in areas with some experience of AIDS reporting, but even in these areas a quarter of respondents would offer the test only to patients considered at risk. This reliance on the physician's own impression about the presence or absence of risk behaviour may increasingly be regarded as inappropriate as numbers increase.

The proportion of respondents routinely offering HIV testing to candidates for transplantation was higher than the proportion offering the test to candidates for dialysis. Even so, one in 10 thought it unnecessary to carry out testing in candidates for transplantation. Given the immunosuppressive treatment required after transplantation, this $10 \%$ may reflect units in which HIV is not perceived as an issue rather than a liberal approach to contraindications to transplantation.

There was considerable variation in the proportion of respondents who considered that a positive HIV test result should exclude a patient from each type of treatment strategy. The consensus among 80 of 87 respondents was that they would not refuse peritoneal dialysis, whereas 24 of 88 would refuse haemodialysis and 63 of 86 would refuse transplantation. Though the International Transplantation Registry had in 1988 documented over $20 \mathrm{HIV}$ positive people given 
TABLE IV-Replies to questions about knowledge and consent of patients tested for HIV. Figures are numbers of nephrologists

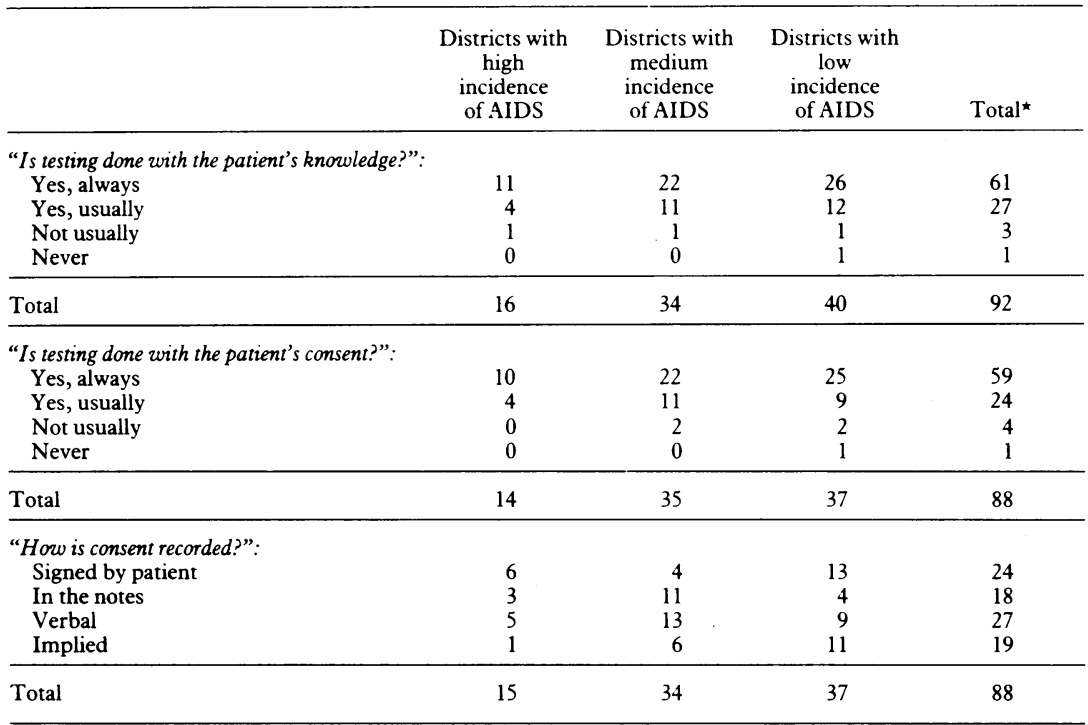

«Total includes two "unknowns."

transplants, ${ }^{17}$ the $27 \%$ of respondents $(23 / 86)$ who would not exclude a patient from transplantation was surprising, given the problem with immunosuppression. This, however, may reflect caution about the assumption that organ recipients who are HIV positive will have a poor outcome. Dummer $e t$ al found that HIV infection was not exacerbated by immunosuppressive treatment. ${ }^{18} \mathrm{M} \mathrm{H}$ Cooper et al, who studied the survival of patients given liver, heart, or kidney transplants, found a two year survival of $52 \%$ (13/25 cases) among HIV positive liver transplant recipients as compared with $72 \%$ among HIV negative controls (abstract presented at British Transplantation Society meeting, Royal Society of Medicine, London, autumn 1989). Of their 13 survivors, 12 had normally functioning grafts. Both Cooper $e t a l$ and Dummer et al therefore considered that HIV was not an absolute contraindication to transplantation. In the case of renal failure, however, dialysis offers a lifesaving alternative to transplantation.

The minority of respondents in our study who would refuse haemodialysis contrasts with the majority in Miami reported by Bourgoigne and Inkerian, who also noted an overall lack of uniformity of practice. ${ }^{19}$ The refusers may be concerned at the potential outcome for HIV positive patients. Evidence suggests that the outcome may be poor in patients with AIDS or HIV nephropathy ${ }^{20}$ but not in patients who are asymptomatic HIV carriers. ${ }^{21}$ Refusers may be concerned that a parallel problem to that associated with hepatitis B virus in haemodialysis units may occur in HIV. So far, however, the evidence is against nosocomial spread of HIV in haemodialysis units. ${ }^{22-24}$ The consequences of nosocomial spread would be catastrophic. We know of no analogous concern in the case of peritoneal dialysis. Peritoneal dialysis has been suggested as the preferred treatment for HIV positive patients with renal failure, requiring only careful fluid disposal procedures. ${ }^{25}$

Rules for getting the patient's consent to HIV testing have been established both by the $\mathrm{BMA}^{23}$ and by the GMC. $^{+5}$ Though two thirds of the respondents in our series always sought consent and a further $27 \%(24 / 88)$ usually did so, the fact that these $27 \%$ sometimes did not and 4\% (4/88) did not seek consent is notable.
Furthermore, of the respondents who sought consent, only $24(27 \%)$ asked for it in writing. Verbal or implied consent was accepted by more than half.

Nephrology is probably in the same position over patient consent to testing as many hospital specialties not principally dealing with HIV and AIDS. The BMA's Foundation for AIDS recognises instances where a doctor thinks it is against the patient's interests to follow guidelines on consent but states that he or she "must be fully prepared to justify his action in the courts or to the GMC or both."26

We conclude that awareness of HIV is probably still rising in many sectors of medical practice. Renal replacement therapy, where different modes of treatment exist and where there has been an acknowledged rationing of potentially lifesaving strategies, ${ }^{13}$ presents a particularly apposite case study. This survey has shown a wide variation in current attitudes to HIV testing among nephrologists in Great Britain and Ireland. Further discussion seems necessary and desirable to achieve consensus on this issue.

1 Weiss R, Thier S. HIV testing is the answer-What's the question? $N$ Engl $f$ Med 1988;319:1010-2.

Sherrard M, Gatt I. Human immunodeficiency virus (HIV) antibody testing Guidance from an opinion provided for the British Medical Association. BrMed f 1987;295:911-2.

3 Anonymous. HIV antibody testing: summary of BMA guidance. $\mathrm{Br} \mathrm{Med} \mathcal{F}$ 1987;295:940.

4 Anonymous. GMC considers further advice on treating patients with AIDS Br Med F 1987;295:1292.

5 Anonymous. General Medical Council agrees guidelines on AIDS. Br Med $\mathcal{J}$ 1988;296:1613.

6 Sherer R. Physician use of the HIV antibody test. FAMA 1988;259:264-5.

Keidan AJ, Franklin IM, Pinching AJ. Testing for HIV: the non-medicolegal view. BrMed f 1988;296:288.

8 Rodger R, Tapson J, Codd A. Markers of HTLV-III in patients with end stage renal failure. BrMed f 1986;293:565.

9 Baillod R, Lui S, Sweny P, et al. Markers of HTLV-III in patients with end stage renal failure treated by haemodialysis. Br Med f 1986;293:819.

10 United Network for Organ Sharing Policies on AIDS and Transplantation. Screening potential organ donors for anti-HIV antibody. Dialysis and Transplantation 1988;17:286.

11 Brunner FP, Fassbinder W, Broyer M, et al. Combined report on renal dialysis and transplantation in Europe. XVIII. Basle: Springer International, 1987.

12 Anderson VC, Gorgone BC, Marlink RG, et al. Transfusion-acquired human immunodeficiency virus infection among immunocompromised persons. Am Intem Med 1986;105:519.

13 Challah S, Wing AJ, Bauer R, Morris RW, Schroeder SA. Negative selection of patients for dialysis and transplantation in the United Kingdom. Br Med $f$ 1984;288:1119-22.

14 Venkateswata Rao K. The impact of AIDS on the management of ESRD patients. Dialysis and Transplantation 1988;17:285-8.

15 European Dialysis and Transplant Association. Combined report XVI. Basle: Springer International, 1985.

16 European Dialysis and Transplant Association. Combined report XVII. Basle: Springer International, 1986

17 Chatteriee S. An uncertain future: AIDS and transplantation. Dialysis and Transplantation 1988;17:285.

18 Dummer JS, Erb S, Breinig MK, et al. Infection with human immunodeficiency virus in the Pittsburgh transplant populations. Transplantation 1989;47:134-9.

19 Bourgoigne J, Inkerian C. Impact of human immunodeficiency virus on the treatment of uraemia. Seminars in Dialysis 1988;1:187-8.

20 Rao T. Maintenance dialysis in patients with human immunodeficiency virus infection. Seminars in Dialysis 1988;1:203-7.

21 Ortiz C, Meneses R, Jaffe D, Fernandez J, Perez G, Bourgoigne J. Outcome of patients with immunodeficiency virus on maintenance hemodialysis. Kidney Int 1988;34:248-53.

22 Chirgwin K, Rao T, Landesman S, Friedman EA. High seroprevalence of antibodies to human immunodeficiency virus in a Brooklyn maintenance hemodialysis unit: preliminary observations. ASAIO Trans 1988;34: 194-5.

23 Perez G, Ortiz C, De Medina M, Shiffe E, Bourgoigne J. Lack of transmission of human immunodeficiency virus in chronic hemodialysis patients. $A m \mathcal{F}$ Nephrol 1988;8:123-6.

24 Assogba U, Park RA, Rey M, Barthelemy A, Rottenbourg J, Gluckman J. Prospective study of HIV I seropositive patients in haemodialysis centres. Prospective study of HIV

25 Williams P, Swan B, Cunningham K. Continuous ambulatory peritoneal dialysis fluid: another fluid positive for HIV antibody. Br Med F 1986;293:

26 British Medical Association. Foundation for AIDS, HIV infection and AIDSethical considerations for the medical profession. London: BMA Foundation, 1988.

(Accepted 27 December 1989) 